\title{
EQUITABLE SELF-OWNERSHIP FOR ANIMALS
}

\author{
DAVID FAVRE $\dagger$
}

\begin{abstract}
This Article proposes a new use of existing property law concepts to change the juristic personhood status of animals. Presently, animals are classified as personal property, which gives them no status or standing in the legal system for the protection or promotion of their interests. Professor Favre suggest that it is possible and appropriate to divide living property into its legal and equitable components, and then to transfer the equitable title of an animal from the legal title holder to the animal herself. This would create a new, limited form of self-ownership in an animal, an equitably self-owned animal.

Such a new status would have two primary impacts. First, the animal would have access to the legal system, at least in what has historically been the realm of equity, for the protection and assertion of his or her interests. Secondly, the human holder of legal title will, like a traditional trustee, have obligations to the equitable owner of the animal, that is the animal himself. As the subject matter of this trust-like relationship would be a living being, not money or wealth, the legal owner would best be characterized as a guardian, rather than by the traditional category of trustee. The Article concludes with a short discussion of the use of anti-cruelty law and human guardianship concepts as providing a context for the further development of this new concept of equitable self-ownership.
\end{abstract}

Copyright $(0) 2000$ by David Favre.

$\dagger$ Professor of Law, Michigan State University-Detroit College of Law. Professor Favre has been involved with legal animal issues for over 20 years as a board member of the Animal Legal Defense Fund. The author wishes to thank a number of people who helped with researching and editing the material contained in this Article, including Joyce Tischler, Steve Ann Chambers, Barbara Newell, David Wolfson, Henry Cohen, and Michael Kelly. 


\section{TABLE OF CONTENTS}

Introduction

I. Understanding and Modifying Principles of Property Law ....477

A. An Overview of Ownership..............................................47

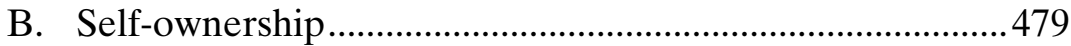

II. Creation of the New Equitable Property Interest.....................484

A. The Roots of the Concept of Equity and Equitable Title

B. The Division of Ownership into its Legal and

Equitable Aspects

C. Transforming Title into Legal Personhood

D. Human Retention of Legal Title and Duty of Care

III. Some Attributes of Being a Self-owned Animal....

A. Shift from Trustee to Guardian

B. The Dimensions and Initial Contours of Equitable Self-ownership

\section{INTRODUCTION}

There is fair consensus among scholars that nonhuman animals within the control of humans are presently considered personal property, with title being held by humans or human substitutes such as corporations or state governments. Several authors have set out in some detail the facts relating to the present use of animals by humans. ${ }^{1}$ In the arenas of moral philosophy and legal jurisprudence, the status of animals has long been under discussion, with the result being a number of proposals supporting the proposition that animals are moral persons ${ }^{2}$ and, as moral persons, are entitled to have legal

1. See, e.g., JoHn A. Hoyt, ANIMALs IN PERIL 95-108 (1994) (addressing wildlife issues); Susan L. Goodkin, The Evolution of Animal Rights, 18 COLUM. HUM. RTS. L. REV. 259, 261-67 (1987) (describing the treatment of laboratory animals); David J. Wolfson, Beyond the Law: Agribusiness and the Systemic Abuse of Animals Raised for Food or Food Production, 2 ANIMAL L. 123, 133-35 (1996) (giving examples of accepted farm practices); Forum: The Benefits and Ethics of Animal Research, SCI. AM., Feb. 1997, at 79-93 (debating the necessity and utility of animal experimentation).

2. If animals are moral persons, then their interests need to be taken into account in moral decisionmaking. See ANimal Rights AND Human Obligations passim (Tom Regan \& Peter Singer eds., 1976) (collecting essays from classical to modern times on animal nature, human obligation, and animal rights); TOM REgAN, THE CASE FOR ANIMAL Rights 235-41 (1983) (developing a theory of animal rights rooted in animals' nature-their consciousness, sentience, and ability to have beliefs, preferences, and emotions); PETER Singer, ANIMAL LIBERATION 123 (1977) (arguing that humans' current treatment of other species is based on arbitrary discrimination); Mary Midgley, Persons and Non-Persons, in IN DEFENSE OF ANIMALS 52-62 
rights. ${ }^{3}$ However, the present legal paradigm, which has its roots in Greek philosophy, is inadequate for the recognition and protection of the interests of animals. ${ }^{4}$ This Article does not seek to establish the necessity for change; rather, it assumes change is justified. ${ }^{5}$

In recent years, several authors have criticized the property status of animals and have sought a new, nonproperty status for animals in our legal system. Two authors in particular have argued for

(Peter Singer ed., 1985) (claiming that emotional complexity, rather than intellectual ability, is the defining characteristic of personhood); Juan Carlos Gómez et al., Nonhuman Personhood, in ETICA \& ANIMALI (1998) (presenting, through a series of essays, arguments for personhood as a moral designation). If animals are moral persons, then should they not also be legal persons and have their interests protected within the legal system? One of the first writers on the issue was Henry Salt, who in 1912 published a short work that started with the sentence: "Have the lower animals 'rights?' Undoubtedly_if men have." Henry S. Salt, Animals' Rights, in ANIMAL RightS AND HUMAN OBLIGATIONS, supra, at 173-78. The roots of the moral debate are centuries old, with Jeremy Bentham perhaps being one of the key figures in the debate. See Jeremy Bentham, A Utilitarian View, in ANIMAL RIGHTS AND HumAN OBLIGATIONS, supra, at 129-30 (basing consideration for animals not on their linguistic or rational capacities but on their capacity for suffering).

3. See Gary L. Francione, Rain Without Thunder: The Ideology of THE ANIMAL Rights MOVEMENT 1-31 (1996) (criticizing the animal welfare movement as advocating that animal exploitation be merely regulated rather than abolished); Steven M. Wise, The Legal Thinghood of Nonhuman Animals, 23 B.C. ENVTL. AfF. L. REV. 471, 546 (1996) (tracing the conception of animals as things from ancient cosmology to modern law); see also Thomas G. Kelch, The Role of the Rational and the Emotive in a Theory of Animal Rights, 27 B.C. EnVtl. AfF. L. ReV. 1, 2-3 (1999) [hereinafter Kelch, Role of the Rational] (concluding that there is no single principle on which to base animal rights and that compassion has been neglected as a basis for rights theory); Thomas G. Kelch, Toward a Non-Property Status for Animals, 6 N.Y.U. ENVTL. L.J. 531, 582 (1998) [hereinafter Kelch, Non-Property Status] (arguing that animal rights should be teleologically based, rather than based on special characteristics such as sensibility and identity over time, in order to protect a broader range of creatures)

4. See Steven M. Wise, How Nonhuman Animals Were Trapped in a Nonexistent Universe, 1 ANIMAL L. 15, 18-30 (1995) (explaining how the "chain of being" view of the universe as set out by the Greek philosophers created a construct under which the Greek and Roman legal system allowed humans total domination of other animals, as well as children and slaves).

5. Several writers have recently expressed opposition to the concept of changing the legal status of animals. See Richard A. Epstein, The Next Rights Revolution?, NAT'L REV., Nov. 8, 1999, at 44, 44 (claiming that to understand animals as anything other than property would undermine human society); Marshall H. Tanick, Legal Terminology Could Prove Punitive to Dog Owners, DOG WORLD, Jan. 2000, at 95, 95-96 (warning that if dog owners are considered guardians, they will be held to an unrealistically high standard of care); see also David R. Schmahmann \& Lori J. Polacheck, The Case Against Rights for Animals, 22 B.C. ENVTL. AFF. L. REV. 747 (1995) (portraying animal rights as a challenge to human progress and freedom). Some nonlegal writers think the issue is a joke and only worthy of a few lines of satire. See Walter Shapiro, Kangaroo Court? A Case of Animal-Rights Absurdity, USA TODAY, Aug. 20, 1999, at 8A; Frans B.M. de Waal, We the People (and Other Animals) ..., N.Y. Times, Aug. 20, 1999, at A21. Both of these articles were in response to an article in the New York Times that discussed the growing movement for animal rights within the legal profession. See William Glaberson, Legal Pioneers Seek to Raise Lowly Status of Animals, N.Y. TIMES, Aug. 18, 1999, at A1; see also William Glaberson, Redefining a Jury of Their Peers, N.Y. TIMES, Aug. 22, 1999, $\S 4$, at 1 . 
the extension of existing common law "rights" principles to nonhuman animals. ${ }^{6}$ This Article proposes an intermediate ground between being only property and being freed of property status, where the interests of animals are recognized by the legal system but the framework of property law is still used for limited purposes.

As will be developed in this Article, it is possible to imagine and articulate a legal paradigm in which a nonhuman animal has equitable self-ownership and, thus, status within the legal system, while a human retains legal title to the animal in question. The analysis that supports this position will require a consideration of the root concepts of property law, as well as a few new concepts, including the idea that living entities inherently possess self-ownership. The legal history that allows the division of property into legal and equitable title will be examined and found to support the proposition that the equitable title of an animal can be separated from the legal title. ${ }^{7}$ Then it will be shown that it is possible to change an animal's personhood status within the legal system by transferring the equitable title of an animal to the animal, creating for the animal a limited form of selfownership. ${ }^{8}$ Having envisioned a new legal status for animals, the Article will then briefly consider the legal relationship between the owner of legal title, the guardian of the animal, and the equitably selfowned animal. ${ }^{9}$ In particular, the Article will examine some of the interests of animals that the legal system will need to acknowledge and take into account when making decisions affecting the well-being of the equitably self-owned animal.

6. See Kelch, Non-Property Status, supra note 3, at 545-54, 580-84 (surveying existing laws and the ability of the common law to change and urging a new approach); Steven M. Wise, Hardly a Revolution: The Eligibility of Nonhuman Animals for Dignity-Rights in a Liberal Democracy, 22 VT. L. REV. 793 (1998) (analyzing the development of "rights" in the common law context and how animals rights can be justified under a traditional "rights" framework). But see infra notes 85-88 and accompanying text (arguing that, at least for the time being, legal ownership should continue to exist).

7. See infra notes 56-62 and accompanying text.

8. See infra notes 63-84 and accompanying text.

9. See infra notes 89-107 and accompanying text. 


\section{UNDERSTANDING AND MODIFYING PRINCIPLES OF PROPERTY LAW}

\section{A. An Overview of Ownership}

The concept of property is one of the fundamental organizing points for any legal system. ${ }^{10}$ Anything of physical substance ${ }^{11}$ is subject to its conceptual organization. The right to control, direct, or consume things-living or nonliving - is allocated or decided within our society under the legal concept of title to property. ${ }^{12}$ The rules of each sovereign country control the property within its jurisdictional boundaries. The concepts discussed below arise out of our English common law roots and are shared by all common law countries. While much of this Article also applies to civil law system states, a separate analysis would have to be performed for the finer points of the civil law. ${ }^{13}$

Before proceeding to animal-specific issues, consideration must be given to the concept of title. To have title is to have a cluster of legally enforceable rights relative to a given object. ${ }^{14}$ Concepts of title are entirely abstract and dependent upon the legal system in which the object is located. Legal rights, or the relationship between the title holder and the object, may well change as the object moves from one jurisdiction to another. For example, historically, in some states within the United States, humans were the property of other humans, and the slave laws of those states established the property rights of

10. "In civilized society, men must be able to assume that they may control for beneficial purposes what they have discovered and appropriated to their own use, what they have created by their own labor, and what they have acquired under the existing social and economic order." Roscoe Pound, The History and System of the Common LAw 263 (1939); see also The Nature of Property and Value of Justice, in THE NATURE AND PROCESS OF LAW 365-433 (Patricia Smith ed., 1993) (assembling essays on the definition of and justification for property).

11. Obviously, property law also deals with the nonphysical in such areas as intellectual property rights, but the issues of nonphysical property will not be considered in this Article.

12. "[P]roperty means not the thing itself, but the rights which inhere in it." WALTER B. RaUshenbush, Brown ON PeRsonal Property § 1.5 (3d ed. 1975).

13. As much of animal jurisprudence is based upon Greek philosophy and Roman jurisprudence, its principal concepts were established well before the division between civil and common law. See Wise, supra note 4, at 42 . For example, in the Supreme Court case of Geer v. Connecticut, 161 U.S. 519 (1896), the Court developed the concept of the state ownership doctrine with a historical review of Roman law as well as subsequent developments in both civil and common law jurisdictions. See id. at 522-27.

14. For a discussion of the rights of property ownership, see POUND, supra note 10, at 28485. The word "object" is used at this stage because it is not yet necessary to distinguish between animate and inanimate subjects, but such a distinction will soon be important. 
the owners. ${ }^{15}$ If an owner took a slave into another jurisdiction, then different laws would apply. ${ }^{16}$ At one point, England adopted the proposition that any slave brought into its jurisdiction was freed immediately, thus entirely destroying the property interest of the slave owner. ${ }^{17}$

There are no characteristics within physical objects that demand a particular set of rules or definitions of the concept of title. However, because of the nature of human beings, rules of title are a prerequisite to order and efficiency within human society. ${ }^{18}$ Humans seek to possess, use, and consume objects. The rules of title create a predictable matrix that sets out who may use which type of objects and what kinds of uses may be made of the object. Rules of property interrelate closely to help direct the economic structure of a country. As these rules are an ordering point for human society, they have a profound impact on how the members of that society view the world around them.

In the United States, the governments of the individual states control ownership under property law concepts. ${ }^{19}$ As the concept of title predates the creation of our state governments, it is a common

15. For example, the Civil Code of Louisiana stated:

A slave is one who is in the power of a master to whom he belongs. The master may sell him, dispose of his person, his industry and his labor. He can do nothing, possess nothing, nor acquire any thing, but what must belong to his master. (Civil Code, Art. 35.)

The slave is entirely subject to the will of his master, who may correct and chastise him, though not with unusual rigor, or so as to maim and mutilate him, or expose him to the danger of loss of life, or to cause him death. (Art. 173.)

William GOODELL, THE AMERICAN SLAVE CODE 23 (1853) (quotations omitted).

16. For full discussion of the circumstances under which slaves could become free by going into other states, see 1 THOMAS R.R. COBB, AN INQUIRY INTO THE LAW OF NEGRO SLAVERY 116-25 (1858).

17. In the case of Somerset v. Stewart, 98 Eng. Rep. 499 (K.B. 1772), Lord Mansfield held that once on English soil, a master could not use the law to seize a slave and remove him or her from the jurisdiction. See id. at 510; see also William M. Wiecek, Somerset: Lord Mansfield and the Legitimacy of Slavery in the Anglo-American World, 42 U. CHI. L. REV. 86, 87 (1974) (considering the opinion to be ambiguous, but influential for the abolitionist cause).

18. See generally THE NATURE AND PROCESS OF LAW, supra note 10, at 365-433 (presenting theories of property); A. M. Honoré, Ownership, in THE NATURE AND PROCESS OF LAw, supra note 10, at 370 ("Ownership is one of the characteristic institutions of human society.").

19. Under the Tenth Amendment of the U.S. Constitution, it is noted that powers not delegated to the federal government are "reserved to the states." U.S. CONST. amend. X. As no delegation exists in the U.S. Constitution, property law remains in the province of the laws of the states. 
law topic..$^{20}$ As such, either the state courts or the state legislatures are fully empowered to deal with the issue of ownership of animals. At this level of government, there have long existed principles of the equitable ownership of property in the contexts both of trusts and the division of land title. ${ }^{21}$

One other preliminary point is that our common law system allows for a distinction between title and possession. As we will see, while human possession may be critical to create initial "title" in an animal, once title to an object is obtained, then possession by the title holder need not be retained in order to prove title. Title to your car or dog is not transferred when you let a friend borrow him or her for a week; instead, a bailment is created. ${ }^{22}$

It will be helpful to use the following examples to delve into the present state of property jurisprudence. Property law creates a relational overlay between objects in the physical world and the humans who own or possess them. We will begin by placing an identification tag on a number of physical objects within the physical boundaries of the United States. Consider a rock (of considerable age), a newborn squirrel, a newborn cat, and a newborn human. Each has its own identification tag: rock \#R188A located on land in Redford, Washington; squirrel S-4444 born in the Yellowstone National Forest; cat \#54376 (referred to as Zoe for easy reference), born of Starburst and Big Bo in the house of Ralph and Penny Willard (humans); and a female human, \#256,332,881, known as Susan, born of Donald and Cindy Greenburg of Lansing, Michigan. Having properly identified these items, the legal concepts of property law can now be used to define the legal status of these four objects and a critical set of potential relationships between them.

\section{B. Self-ownership}

As property laws are a human construct and not an inherent characteristic of physical objects, there is always conceptual space for

20. Blackstone, in his famous work on the law of England, devotes all of Volume II to the issue of property ownership and the transfer of land. See 2 William Blackstone, COMMENTARIES ON THE LAWS OF ENGLAND (Univ. of Chicago Press 1979) (1766). His fourvolume set is a fair reflection of the common law that the states of the United States inherited.

21. See infra Part III.A.

22. See RAUSHENBUSH, supra note $12, \S 1.5$ ("The transaction known as bailment ... arises when an owner of a chattel confers upon another temporary rights of possession but does not divest himself of his ultimate title to the thing in question."). For a full discussion of the bailment of animals, see DAVID FAVRe \& PETER L. BORCHELT, ANimAl LAW AND Dog BEHAVIOR 64-77 (1999). 
innovation. One of the premises for our new property paradigm is that living objects have "self-ownership." That is, unless a human has affirmatively asserted lawful dominion and control so as to obtain title to a living object, then a living entity will be considered to have self-ownership. As will be shown, this is but a modest recasting of existing concepts, but one with significant consequences.

Our existing legal system does not now assert ownership in all physical things. Meteorites in the sky have no human-designated title, and particular molecules of water and air in their natural state have no human title constraining and defining them. ${ }^{23}$ Nor do newborn squirrels in the wilderness, or human babies in Lansing, Michigan, have human-based title claims against them. As will be seen, however, not all of these objects qualify for the concept of self-ownership, as the object in question must first be a "being."

In whichever category non-owned objects might be placed, our legal system does have a number of rules that allow humans to obtain ownership. Usually, as a prerequisite to title being acknowledged in a human, some assertion of possession and control over an object must be made by the person seeking title. This is logical, as the concept of title deals with the use and control of objects: until an object is within the possession and control of some human, the law will be without effect, and there will be no reason to assert title over an object.

As a wild animal, the squirrel of Yellowstone is not yet humancontrolled; she retains self-direction, self-control and self-ownership. ${ }^{24}$ It is a misperception of existing property law to say that title is in the state when wildlife exists in its natural environment. ${ }^{25}$ If no human or human substitute has possession and control over a wild animal, there cannot be an assertion of title. ${ }^{26}$ The courts have long made it clear

23. See RAUSHENBUSH, supra note $12, \S 1.6$ ("Certain physical things, such as air, light, and running water, are by their very nature incapable of being owned.").

24. The first two categories are physical realities, while the third is a legal category. There does not have to be self-awareness of a legal status in order for society to recognize the status.

25. See RAUSHENBUSH, supra note $12, \S 1.6$ ("Wild animals, birds and fish are also in their natural state not objects of private ownership, though in this case they may become such by being reduced to the possession of an individual."); see also FAVRE \& BORCHELT, supra note 22 , at 36 ("[C]haracterizing the state as being an owner of wildlife is misleading and not particularly helpful in understanding the responsibilities of the state and the many expressed limitations thereupon.").

26. See FAVRE \& BORCHELT, supra note 22, at 27:

While the rule for obtaining title is relatively easy to state, a determination of facts sufficient to satisfy the requirement of possession is much more difficult to state in the abstract. Reduction to possession must be considered on a case by case basis and will focus on the issue of physical dominion and control. The classic case is that of Pierson 
that using the word "title" as it relates to wildlife and state ownership issues is not title in the property sense. Rather, the word is being used as a surrogate for a different concept. The assertion of the common law is not that the state has title to the wild squirrel, but that it has the right to decide the conditions under which humans can obtain title to the squirrel. ${ }^{27}$ Under these rules, if Susan shows up in Yellowstone National Forest and traps or shoots the squirrel, then the property rules of the state of Utah will decide if she becomes the owner of the squirrel, if she obtains "title" to the squirrel. Until the point of capture, the squirrel has self-ownership. Assuming that the property rules of the state allow Susan to assert title with the capture of the animal, then self-ownership is lost or transformed into human ownership. The fragility of the title asserted by humans over wildlife is reinforced by the existence of the property rule that that if the squirrel escapes back into its natural habitat, then Susan will lose her title. It evaporates with the disappearing squirrel. ${ }^{28}$ Thus, the existing property rules relating to wild animals do not hinder assertions of self-ownership.

Also, under existing concepts, it is fair to state that the newborn human is self-owned. ${ }^{29}$ Certainly in the negative sense, no one else is

v. Post. Post was in full pursuit of a particular fox with horses and hounds. Pierson, with full knowledge of Post's pursuit, shot and killed the fox, taking physical possession of the fox. Post claimed his pursuit sufficiently diligent and active to give him a superior interest in the fox. The court disagreed, saying that pursuit, without wounding, circumventing, or ensnaring, so as to deprive an animal of natural liberty and gain control over it, was insufficient to give rise to any property interest in the fox.

27. See RAUSHENBUSH, supra note $12, \S 1.6$ :

There are judicial and statutory statements to the effect that the state in its sovereign capacity has title to the game within its borders in trust for the benefit of its people. This is, however, not much more than a metaphor for the undoubted truth that the state may, by virtue of its police power, regulate hunting and fishing within its borders so as to preserve for the benefit of all the wildlife with which it has been endowed by nature.

For discussion of state regulations limiting the obtaining of title of wildlife, see FAVRE \& BORCHELT, supra note 22, at 38-42; see also Leger v. Louisiana Dep't of Wildlife \& Fisheries, 306 So. 2d 391, 394 (La. 1975) (finding the state not liable for damages by wild animals because the state did not own the animal in its proprietary capacity, but only in its sovereign one).

28. See FAVRE \& BORCHELT, supra note 22, at 33-36; RAUSHENBUSH, supra note 12, § 2.5.

29. The legal concepts are based upon philosophical precepts of self-ownership:

Both natural rights theorists, such as Locke, and personalists, such as Hegel, presume that a property right in the human body exists. Locke begins with the premise that "every Man has a Property in his own Person." He continues, "[t]he Labour of his Body, and the Work of his Hands ... are properly his." Property is created when an individual expends labor on an object. For Locke, an individual's ownership of his body and labor is the postulate that enables man to own things external to himself. 
the owner of human Susan. ${ }^{30}$ The extent to which state legislatures have sought to regulate the sale of human body parts is additional support for the conceptual existence of human self-ownership. ${ }^{31}$ Susan's parents, while not having ownership, nevertheless have obligations toward Susan, and while she is a minor they certainly have physical possession and considerable control over Susan and what she experiences. ${ }^{32}$ But within the common law states today, these obligations do not rise to the level of having title in Susan, that is, the ability to use, kill, or transfer ownership to another. So our human child, like the squirrel, is not a being owned by a human and, therefore, must be considered to have self-ownership.

Our rock poses a different kind of problem. It has no "self" to which the concept of self-ownership can attach. It is not alive. Also, assuming that this rock, like all ageless rocks, is sitting on a tract of land, then property law dictates that the owner of the land has ownership of all the rocks located on, below, and above the land itself. $^{33}$ The rock is part of the land ownership. Within the United States, all land is owned by someone-if not a private party, then by a

Only because people have physical ownership of their bodies do they have an ownership of their bodies' products.

Michelle Bourianoff Bray, Note, Personalizing Personalty: Toward a Property Right in Human Bodies, 69 Tex. L. Rev. 209, 212 (1990) (quoting J. Locke, Two Treatises OF GovernMent $\S 27$ (1698)) (internal citations omitted). See, e.g., Moore v. Regents of the Univ. of Cal., 249 Cal. Rptr. 494, 503-05 (1988), aff'd in part, rev'd in part, 793 P.2d 479 (Cal. 1990) (concluding that absent a lawful justification such as consent or abandonment, a person has a property right in her own bodily tissues and organs); RICHARD GOLD, BODY PARTS: PROPERTY RIGHTS AND THE OWNERSHIP OF HuMAN Biological MATERIALS 23-40 (1996) (discussing the Moore decision and arguing that not all values represented by the human body fit within the legal property system's financial value construct). For a historical view, see FRANK HALL CHILDS, PRINCIPLES OF THE LAW OF PERSONAL PROPERTY § 111 (1914):

A human body, living or dead, is not the subject of property; therefore a dead human body cannot be inherited, nor is it a subject of larceny, or of a gift causa mortis. . . A dead human body, however, is said to be quasi property, which means that certain persons have rights in regard thereto which will be enforced by the courts.

30. See, e.g., United States v. King, 840 F.2d 1276, 1276 (6th Cir. 1988) ("The Thirteenth Amendment prohibits an individual from selling himself into bondage, and it likewise prohibits a family from selling its child into bondage.... Our law views the child as an individual with the dignity and humanity of other individuals, not as property.").

31. In the absence of prohibitory or regulatory law, humans would have the ability to sell or transfer parts of themselves to others, and such physical transfers would also transfer title to the item. See National Organ Transplant Act (NOTA), 42 U.S.C. §§ 273-74 (1988) (establishing organ procurement organizations and network); UNIF. ANATOMICAL GIFT ACT (UAGA) § 2 (1987), 8A U.L.A. 5 (Supp. 2000) (establishing procedures and criteria for organ gifts).

32. See infra notes $95-98$.

33. See CHILDS, supra note $29, \S 2$ ("Real property is land, things therein, or annexed thereto, the space above the soil, and certain interests in any or all of these."). 
government. ${ }^{34}$ Rocks in the Antarctic and on the moon, where no human asserts ownership of the underlying land, may be free from human ownership claims ${ }^{35}$ but, as rocks have no self-interests, even in these locations it is not useful to say that they have self-ownership.

Last, but certainly not least, is the cat Zoe. While Zoe has a set of self-interests to which can be attached the concept of selfownership, title to her, unlike the Yellowstone squirrel, already rests in another: the human owner of the mother of Zoe is considered to be the owner of all offspring of the animal. ${ }^{36}$ Title to Zoe rests with the Willards. ${ }^{37}$ This ownership is distinguished from the ownership of the rock primarily by the fact that prevention-of-cruelty laws apply to owners of pets but not to owners of rocks. ${ }^{38}$ Also, while rocks do not tend to harm humans of their own accord, animals can cause harm, and their owners may be liable for such harm. ${ }^{39}$ The Willards can sell the cat, give the cat away, put the cat in a trust, leave the cat by will to Aunt Mae, or kill the cat in a non-cruel manner. ${ }^{40}$ In making decisions

34. Inherent in the concept of a sovereign state is control or ownership of all land within its boundaries.

35. An analogy with the rules of the capture of wildlife can be made to American astronauts picking up rocks from the surface of the moon. By taking possession and control of the rocks, they obtained title to the rocks. An additional property question is whether they obtained title for themselves, or rather, as employees of the United States, they obtained title on behalf of the United States government.

36. See Carruth v. Easterling, 150 So. 2d 852, 855 (Miss. 1963); West v. Ankney, 134 N.E.2d 185, 192 (Ohio 1956); Kauffman v. Stenger, 30 A.2d 239, 241 (Pa. 1943); FAVRE \& BORCHELT, supra note 22 , at 25 .

37. Who specifically has title to a pet is often a difficult issue, as seldom is anything reduced to writing. There is not normally a birth certificate or a bill of sale identifying the purchaser. Families often purchase or obtain pets as a group. If so, is there a joint ownership between the husband and wife (and children) or is ownership in one of their names alone? If there is a divorce between the humans, then the issue of who gets the pets can become a point of contention.

38. Anti-cruelty laws are a restriction on the conduct of humans. While they clearly apply to the owners of animals, they also apply to others who simply interact with animals. See MiCH. COMP. L. § 750.50(2) (1994) ("An owner, possessor, or person having the charge or custody of an animal shall not ... [c]ruelly drive, work, or beat an animal, or cause an animal to be cruelly driven, worked, or beaten.”); DAVID FAVRE \& MURRAY LORING, ANIMAL LAW 123-44 (1983). As rocks are not animals, comparable restrictions of human conduct vis-à-vis the rock do not exist. There is a second category of statutes applying to owners and possessors of animals. These statutes impose an affirmative duty of care on the human for the benefit of the animal. See FAVRE \& LORING, supra, at 144-48. For example, the Michigan code states: "'Adequate care' means the provision of sufficient food, water, shelter, sanitary conditions, exercise, and veterinary medical attention in order to maintain an animal in a state of good health." MICH. COMP. L. § 750.50(1)(a) (1994).

39. See FAVRE \& BORCHELT, supra note 22, at 131-60.

40. Most cruelty laws do not prohibit the killing of an animal; they just prescribe the manner of killing. 
about the cat, the Willards may or may not adopt those courses of action which are in the best interest of the cat.

The focus of this Article is to shift the nature of the relationship between the owner and the animal from that which is like the ownership of the rock to that which is more like, but not identical to, the custodial relationship of the human parent and the human child. The concept of self-ownership is one useful construct towards this new view. While this proposition is not compelled by existing legal precedent, its establishment is not significantly hindered by existing legal precedent either. The critical hurdle for acceptance of this new concept is the perceptions and beliefs of individuals. If an individual believes that nonhuman animals are deserving of consideration in our moral and legal universe, then the legal concept of self-ownership will find fertile ground in which to flourish. Having established the concept of self-ownership of living beings not owned by humans, the focus of the Article will now turn to the creation of a legal mechanism which will allow the law to recognize self-ownership for those animals presently owned by humans.

\section{CReation of the New Equitable Property Interest}

\section{A. The Roots of the Concept of Equity and Equitable Title}

For several centuries after William the Conqueror initiated the feudal system in England (1066), all that existed in common law England relating to the ownership of land were the concepts clustering around the idea of feudal tenure which would evolve into legal title. ${ }^{41}$ During this time there was considerable evolution as to the scope of power assertable by the private owner (legal title holder). The law slowly shifted away from the king having primary control over the use of and title to land to the private individual (lords and knights) having primary control. ${ }^{42}$ After the Statute Quia

41. See Cornelius Moynihan, Introduction to the Law of Real Property 1-18 (2d ed. 1988). The first signs of equity appeared within the legal system around 1400. See William B. Stoebuck \& Dale A. Whitman, The Law of Property 18 (3d ed. 2000).

42. For the past 900 years, the most comprehensive land ownership has been held by the owners of the estate known as a "fee simple." But the definition of this term has changed considerably over time from what we would today call a life estate to full powers of alienability and inheritability. See Thomas F. Bergin \& Paul Haskell, Preface to Estates in Land AND FUTURE INTERESTS 7 (2d ed. 1984) ("[L]ands held in feudal knight service immediately after the Conquest were not freely inheritable. A transferee would receive from his transferor simply the right to enjoy the land for life."). For the development of the concept of the fee simple, see MOYNIHAN, supra note 41, at 26-32. 
Emptores (1290), the English land laws began to take a form that we would recognize today, with the individual able to make an inter vivos transfer of interest in land without having to have the permission of the king or an overlord. ${ }^{43}$

Thereafter, there developed a separate set of rules relating to land use and possession, articulated and enforced by the representatives of the king, not the courts, which became known as the rules of equity. The need to implement these rules, which did not seek to overturn the rules of law but to coexist with them, supported the slow creation of a separate legal system, known as the Court of Chancery. ${ }^{44}$ These rules evolved from petitions of mercy granted by the king, to petitions granted by the privy counsel of the king under the supervision of the chancellor, and, ultimately, to a separate court system. ${ }^{45}$ This court is considered to have been in full existence by the end of the reign of Henry $\mathrm{V}(1413-22){ }^{46}$ As the petitions became standardized and the courts' decisions became more predictable, the claims were transformed into equitable rights. ${ }^{47}$ One of the primary concerns of the equitable court was unfair use of the legal rules of ownership by landowners.

For over a century, equitable concepts coexisted as a separate set of rights and obligation for landowners. ${ }^{48}$ During this period, it could be said that land ownership had two sides or aspects, those enforced

43. See MoYniHAN, supra note 41, at 27 ("The concept of the estate in fee simple was developed in the period between the Conquest and the enactment of the Statute Quia Emptores (1290).").

44. See id. at 173:

The Chancellor did not interfere with the legal title of the feoffee to uses. $\mathrm{He}$ recognized the legal title as being in the feoffee but compelled the latter to refrain from making use of that legal title in a manner inconsistent with the promise under which he had received it.... We arrive, then, at this result: as consequence of Chancery's protection of the cestui que use there is now a dual ownership of land, the legal title of the feoffee to uses, or trustee, and the equitable title of the cestui que use - an equitable title that is transferable, inheritable and devisable.

45. See id. at 171 ("The Chancellor, as keeper of the king's conscience, sought to give relief where justice and equity required it even though, or rather because, the suppliant or petitioner could obtain no redress for his grievance in the king's common law courts."); GRANT NEWELL, ELEMENTS OF THE LAW OF REAL PROPERTY § 312 (1902).

46. See Jesse Dukeminier \& JAMEs E. KRIER, Property 267 (4th ed. 1998); see also HENRY MCCLINTOCK, MCCLINTOCK ON EQUITY 3-9 (2d ed. 1948) (describing the origin of the Court of Chancery and the rules of equity).

47. Equity evolved from being simply a private action to being an actual interest in land. See Pound, supra note 10, at 268-69 (1939) (discussing how under contemporary practice, an equitable interest may sometimes be enforceable against the title itself, and not just the title holder).

48. See supra note 41 . 
in equity and those enforced in law. Indeed, an individual could hold an equitable interest in land, which the courts of law would not acknowledge. After the Statute of Uses (1536), many of the equitable rights were migrated into the legal system, and, thus, the courts of equity lost jurisdiction over a number of property title issues. ${ }^{49}$ However, the courts of equity retained jurisdiction when a legal title holder had an active duty for the benefit of another. ${ }^{50}$ In this way, one person could be considered to have legal title and the other equitable title. Today this division remains, and it is the cornerstone for the creation and control of trust, as it allows two individuals to have an interest in the same property, but with different obligations and benefits. ${ }^{51}$

Equitable courts asserted control in broader circumstances than just the issues of land use and ownership. The courts of chancery asserted jurisdiction when they believed that the application of the rules of law resulted in unfair, unjust, or inequitable outcomes. ${ }^{52}$ Equity continues to be the area in our system of jurisprudence that allows the correction of harsh or unfair outcomes. ${ }^{53}$ It deals with obligations and relationships, not with money damages. ${ }^{54}$ For a

49. See StOEbucK \& Whitman, supra note 41, at 91:

Prior to 1536 remainders were the only non-reversionary future interests recognized and protected by the English common law courts. But equitable executory interests, (then called "uses") were recognized and protected by the Court of Chancery during the fifteenth century, and they came to be recognized and protected by the common law courts after enactment of the Statute of Uses in 1536.

50. Most of the rules of equity that related to real property during historical times were clustered around the concept of a "use." The details of this analysis still give law students a headache as the uses spring and shift over time. A transformation of the uses occurred during the reign of Henry VIII when the Statute of Uses was adopted, transforming equitable into legal interests. After another century or so of development, the primary focus for equitable interests was in the creation of trusts (unexecuted uses). See MoYniHAN, supra note 41, at 171-206; NEWELL, supra note 45, §§ 318-29.

51. "A trust is a fiduciary relationship in which one person is the holder of the title to property subject to an equitable obligation to keep or use the property for the benefit of another." GEORGE T. BOGERT, TRUSTS 1 (6th student ed. 1987).

52. Often equity was the basis for the courts' ability to enforce provisions of a person's will dealing with the claims of slaves, who would otherwise not have the ability to claim a legal right. See Clealand v. Waters, 19 Ga. 35, 39 (1855); Leech v. Cooley, 14 Miss. (6 S. \& M.) 93 (1846).

53. Articulating the rudimentary definition of equity, Professor McClintock states:

In the general juristic sense, equity means the power to meet the moral standards of justice in a particular case by a tribunal having discretion to mitigate the rigidity of the application of strict rules of law so as to adapt the relief to the circumstances of the particular case.

MCCLINTOCK, supra note 46, at 1 .

54. In contrast to the form of the judgment at common law in favor of a successful plaintiff, which merely awarded to him a recovery of money or of specific property, the typical relief 
considerable time in the United States, the dual English legal system has been merged into one system for almost all cases. The rules of law and equity for both real and personal property are now exercised by one integrated judicial system. ${ }^{55}$ All this historical development leaves us with two related but separate points. First, property ownership can have a division into legal and equitable title. Second, while there is no longer a court of equity, concepts of equity continue to exist in order to provide flexible tools of fairness for the courts.

\section{B. The Division of Ownership into its Legal and Equitable Aspects}

Today an equitable interest in land is usually created by a deed sufficient to satisfy the requirements of the state in which the land is located. ${ }^{56}$ Thus, present owner O, by deed, may convey an equitable life estate in the family farm to daughter D. After the conveyance, the state of ownership will be that both $\mathrm{O}$ and $\mathrm{D}$ have an interest in the family farm. D has an equitable life estate, and, during D's life, $\mathrm{O}$ has the legal title, plus the remainder in fee simple, both legal and equitable. At the end of D's life, the equitable interest comes back to $\mathrm{O}$, who will thereafter have both legal and equitable fee simple. During D's life, D has the right to use the land or to receive the proceeds from the farming on the land. Because of D's interest, O's title is in the nature of that of a trustee.

Property concepts historically developed first for real property, then many of the attributes of ownership were transposed into the system of personal property. ${ }^{57}$ Thus, today the ownership of personal

granted by the chancellor was in the form of a command directed to the other party ordering him to do or not do some act. See id. at 32.

55. The integration of law and equity started in the first half of the nineteenth century and continued into the beginning of the twentieth century on a state-by-state basis. See id. at 13-16. However, traces of the differences can still be found. The premiere power of equity is the power to issue an injunction, forcing someone to do or not to do some act. Those judicial offices that have the authority to issue injunctions are those wearing the old hats of the court of equity.

56. While the preferred method of creation of equitable interest in personal property is by written instrument, in some circumstances an orally created trust in personal property (particularly when dealing with possible gifts) has been recognized. See RAUSHENBUSH, supra note 12, § 7.21; In re Estate of Smith, 22 A. 916, 916-17 (Pa. 1891) (stating that "“[i]t is well settled that the owner of personal property may impress upon it a valid present trust, either by a declaration that he holds the property in trust, or by a transfer of the legal title"). However, this Article will not pursue all possible options for creation; rather it will presume the clarity of the written instrument, which might be a present title transfer by a deed, a trust, or a future transfer by a lawful will.

57. While human slaves were normally categorized as personal property, apparently some states sought to have them considered more like real property, presumably because there were property attributes available to the owners of real property that were not yet transferable to 
property can also be separated into legal and equitable title. ${ }^{58}$ All owners have the lawful ability to separate the title of their personal property into its two components and convey those separate components to others. ${ }^{59}$ If $\mathrm{O}$ is the owner of one thousand shares of Microsoft stock, $\mathrm{O}$ may have personal and tax motivations for the establishment of a trust. Thus, $\mathrm{O}$ can transfer the stock to a family trust. Under this trust, Trustee $\mathrm{X}$ holds the legal title to the stock (including the power to sell the stock), while son $\mathrm{S}$ has the right to receive the income or the increase in value of the stock on an annual basis so long as $\mathrm{S}$ is alive. ( $\mathrm{S}$ would not have the power to sell or transfer the stock.) This might be desirable because of S's age. S has an equitable (life estate) interest in the stock while $\mathrm{X}$ has the legal title. $\mathrm{X}$ does not have total freedom to do as he or she might with the property. X's legal title, as a trustee, is encumbered with specific duties of loyalty toward $\mathrm{S} .^{60}$

In addition to formal instruments of trust for personal property, the common law has an informal mechanism for sharing title and possession known as a bailment. The owner of a racehorse may say to his daughter, "I want you take my horse Lightning for five years and see if you can make a winner out of him." This would not be a sale or gift of the animal, as the father is not relinquishing present or future ownership. Instead, the legal category most likely to be used to define this relationship is that of a bailment. The father retains title, but the daughter has lawful possession and control of the horse. ${ }^{61}$ This is just

personal property, e.g., to allow owners access to instruments, such as mortgages, or have the ownership of the slave follow the rules of descent at death. See GoODELL, supra note 15, at 24, 30 (describing the property status of slaves in various states).

58. Several centuries ago, personal property could only be held in absolute ownership (fee simple) in the eyes of the courts of law. But the Court of Chancery enforced the creation of lesser estates. For example, if O gives his ring to S for life, then to D after S's death, the original law courts would not have enforced the gift remainder to D but would have given all the interest to S. The Court of Chancery would force S's estate to convey the ring to D after S's death. See Joseph J. Darlington, A Treatise on the LaW of Personal Property 278-84 (1891).

59. See StOebuck \& Whitman, supra note 41, at 171-74 (discussing the separation of law and equity and the protection of the legal future interest of personal property).

60. The trustee owes a duty to the beneficiaries to administer the affairs of the trust solely in the interests of the beneficiaries and to exclude from consideration his own advantages and the welfare of third persons. This is called the duty of loyalty. If the trustee engages in a disloyal transaction, the beneficiary may secure the aid of equity in voiding the act of the trustee or obtaining other appropriate relief, regardless of the good faith of the trustee or the effect of the trustee's conduct on the beneficiary or benefit to the trustee. See BOGERT, supra note 51, at 95.

61. In one case, two parties differed over the terms of possession. Specifically, the parties could not agree upon whether the horse was transferred for only one season or for its racing life. Since both parties agreed that eventually he was to be returned, the court found it to be a bailment and not a gift. See Simpkins v. Ritter, 204 N.W.2d 383, 383-85 (Neb. 1973). 
an informal method of creating a division into legal and equitable title. The daughter has the right to use the horse, but not to sell the horse to another. This relationship is like that of a trust in that the equitable title holder has possession and control over the asset without having the ability to dispose of the legal title of the horse. It is not like a trust in the sense that in this case the legal title holder, the father, can dispose of the title of the horse without regard to the interests of the daughter.

Most of our personal property does not have the value of one thousand shares (or even ten shares) of Microsoft stock or of a racehorse. Therefore, it is seldom worth the transaction costs to formally create legal categories or formally divide the title into two estates. The Willards, in trying to decide what to do with Zoe as she grows up might have any one of the following conversations with their Neighbor:

1. "Zoe is a great little cat, she is yours." (The cat is physically given to Neighbor.) This is a transfer, by gift, of full ownership, of both the legal and equitable title from the Willards to Neighbor.

2. "For payment of $\$ 10$, you may have Zoe for a year and breed her if you wish, but then we want her back." The Willards want to keep title while allowing use and possession to shift to Neighbor. This would most likely be characterized as a bailment. Both parties have an interest in Zoe that a court of equity would recognize (e.g., the court would issue an injunction for the return of the cat if Neighbor refused to do so after a year).

3. "Knowing how much you [Neighbor] have come to love Zoe, we want to you to consider her yours, but we need to keep her for three months." (This declaration is made in the presence of six Willard family members as well as Neighbor.) This may be considered the oral creation of a trust, whereby the Willards retain legal title, but Neighbor immediately receives an equitable interest in Zoe. ${ }^{62}$ Henceforth, the Willards may not do with Zoe as they wish, but must take into account the interests of Neighbor.

Thus, there are a number of possible transactions that allow for multiple party interests in living personal property, where at least one party's interest can best be characterized as equitable in nature. In the

62. See RAUSHENBUSH, supra note $12, \S 7.21$. 
first example, after the physical transfer, the Neighbor could decide to put the cat to death, and the Willards could not object. In the second and third examples, during the time that two interests exist, the possessory estate could not kill the cat because of the interest of the other human. (This analysis assumes the traditional view that even if the cat has an interest in not being killed, she has no legal voice before the courts.)

\section{Transforming Title into Legal Personhood}

Having acknowledged that it is well within the legal mainstream to create and transfer equitable interests in personal property, an expansion of a second, related concept must be considered. Who is capable of holding a legal or equitable title? While historically only humans could hold title, is it not conceptually possible for other living entities be a holder of title, at least to the limited extent of holding their own equitable title? If self-ownership is an acceptable concept, is it not appropriate to say that title is being held by "self"? How might the equitable title of an animal be transferred to the animal itself? Presently the private owner of an animal can do certain intentional acts that impact the title status of the animal beyond the transferring of it to another human. First, an owner can abandon his or her domestic animal. Abandonment is an intentional relinquishment of all title and interest in personal property which should be evidenced by some explicit act. ${ }^{63}$ It may be a criminal act to abandon an animal, ${ }^{64}$ but it can be effective in the property law realm so that the abandoned animal is without title and without a human owner. ${ }^{65}$ An abandoned domestic animal has his or her title (legal and equitable) go into "never-never" land. No one has it, but it is readily obtainable by another human taking possession of the animal. ${ }^{66}$ During this interim, perhaps it is useful to consider the animal itself as possessing the title. But in this case, the animal is incapable of stopping a human from taking/transferring the title upon the occurrence of specific events relating to the exercise of dominion and control over the animal. A second fact pattern is where an owner of a wild animal can

63. See CHILDS, supra note 29 , at 435-37; RAUSHENBUSH, supra note $12, \S 1.6$.

64. See FAVRE \& LORING, supra note 38, at 152-54.

65. See RAUSHENBUSH, supra note 12, $\S 1.6$. The ability to claim ownership of an abandoned animal will depend upon the status of being a "finder." See FAVRE \& BORCHELT, supra note 22, at 28-29.

66. "Thus leaving it [abandoned personal property] to be acquired by any person who subsequently may choose to assert title by occupancy." CHILDS, supra note 29, at 436. 
return title to a wild animal by releasing him back into his natural habitat. As a released wild animal regains self-control, it also regains self-ownership.

If the legal and equitable owner of an animal can change the title status completely by intentional acts, is there a policy reason to object to the returning of part of the title to an animal? Could not an owner of an animal return or transfer the equitable interests of the animal to the animal? Such a transfer would be but a partial return of title, a hybrid form of self-ownership.

The history of our legal system contains a striking parallel to the issues of property status and the transforming of property status into legal personality. There have been times when human beings were held as personal property, but by a property instrument the status (legal personality) of a slave could be changed to that of free person. ${ }^{67}$ Both the mature Roman legal system and the early legal system of the United States dealt with these issues. One difference is that, for most of Rome's history, human slavery was widely accepted as preferable to being slain by the victor's sword during war. ${ }^{68}$ In the United States, there were sharp lines of difference about the moral acceptability of slavery. In both legal systems, the legal status of a slave could change a number of different ways. ${ }^{69}$ In both systems, methods existed by which humans in the status of property could be transformed into legal persons, that is, obtain status within the legal system. This could

67. The analogy to human slavery is not intended to denigrate the group of human beings who were held as slaves, but rather to show that there is precedent within our legal history for the change from property to non-property status. The reference to slavery is an example of an analogous construct of legal thinking that could be applied in similar but not identical circumstances. The parallel exists to the extent that nonhuman animals are living beings with self-interest, even though they are not human beings.

68. See W. W. Buckland, The Roman Law of Slavery 291 (reprinted AMS, 1969) (1908) [hereinafter BUCKLAND, ROMAN LAW] (stating that, under the traditional Roman practice, individuals captured during war became slaves); W. W. BUCKLAND, A MANUAL OF Roman PRIVATE LAW 39 (Cambridge Univ. Press 1928) [hereinafter BUCKLAND, MANUAL] (noting that "[i]t was assumed to be the conqueror's right to kill all prisoners: to save their lives and sell them as slaves was an act of mercy").

69. As slavery existed within the Roman legal system for centuries, a very complex system was developed by the time Justinian set out the laws in his Institutes. See BUCKLAND, ROMAN LAW, supra note 68 , at 397. 
occur by legal instrument done by the owner, or by operation of law, ${ }^{70}$ even if it was against the will of the owner. ${ }^{71}$

In parallel to this history, there are two methods by which a change of legal status might occur for nonhuman animals. The first is by the explicit private action of an existing title holder. An example in the context of this Article would be when an individual owner of an animal signs a carefully drafted instrument which transfers the equitable title of the animal to the animal. ${ }^{72}$ The writing should be sufficient to make clear the owner's intention of creating a new legal status for his or her animal and the understanding that some legal consequences will follow from the action of signing the document. ${ }^{73}$ The signature on the document may or may not reflect the presence of financial consideration (a voluntary sale or a gift inter vivos). This status might also be created by an individual in his or her will. ${ }^{74}$ To

70. Roman law provided a method of declaration of freedom by a magistrate. See BUCKLAND, ROMAN LAW, supra note 68, at 441-42. Also as a matter of law, "a captured Roman regained his old position in law and thus ceased to be a slave as soon as he set foot on Roman soil." BUCKLAND, MANUAL, supra note 68, at 40. However, in the American experience:

$\S 336$. Manumission may be either direct and intentional, or indirect and by implication: of the former class are manumission by deed, by will, or by contract: of the latter, manumission by effect of law, either foreign or domestic and by implication.

CoBB, supra note 16 , at 284.

71. See Abraham Lincoln, Emancipation Proclamation, 12 Stat. 1268 (1863).

72. The United States Supreme Court upheld the right of slave owners to renounce ownership:

As a general proposition, it would seem a little extraordinary to contend, that the owner of property is not at liberty to renounce his right to it, either absolutely, or in any modified manner he may think proper. As between the owner and his slave, it would require the most explicit prohibition by law, to restrain this right.

M'Cutchen v. Marshall, 33 U.S. (8 Pet.) 220 (1834); see also CoBB, supra note 16, at 279 (noting that "[t]he right to manumit a slave, arising from the power of the owner to renounce his right to him, requires no permission or sanction of law to give it validity and effect"). However, one restraint imposed by several of the states of the United States was that an owner could not free a slave if he or she was old or sick. See id. at 282.

73. At common law in the United States, no specific words were required for the freeing of a slave, so long as the words used were "sufficient [to] evidence[] a renunciation of dominion on the part of the master." СоBB, supra note 16, at 287; see also Arthur Howington, "A Property of Special and Peculiar Value": The Tennessee Supreme Court and the Law of Manumission, 44 TENN. HIST. QUART. 302, 303 (1985) (stating that the "Tennessee Court required only that an owner show his intention to emancipate") (internal quotation marks omitted).

74. This was also an important method during the Roman era for the change of status for slaves. "Gratuitous benefits are, naturally, given most readily at death. This mode of manumission was therefore by far the most important in the law." BUCKLAND, ROMAN LAW, supra note 68 , at 442 . 
distinguish animals with this new status (legal personality), they will be referred to as "self-owned animals" (equitably self-owned).

In the human slavery context, one court stated "that unless restrained by positive enactment, a testator may, by his will, effect the manumission of his slaves, by vesting the title to them in trustees, for the purpose of their removal to a free state, there to enjoy their freedom." "The possibility of a change of legal status by private action was available for the Roman as well as the American slave owner. The most common method was by operation of a will. ${ }^{76}$ During portions of the Roman era, inter vivos transfer could also occur. ${ }^{77}$ For most times in the United States, a slave owner could free slaves in his or her will, ${ }^{78}$ or freedom could be purchased or given. ${ }^{79}$ The North Carolina Supreme Court upheld a trust for a slave, allowing the slave to be the beneficial equitable owner of the trust. ${ }^{80}$

One modest issue concerning private transfer of interest should also be addressed: that of delivery of a deed. ${ }^{81}$ Animals are not likely to understand the importance of the document, nor are they able to keep such a document. Additionally, it would be hard for the benefits of the document to be realized unless some third party is aware of the change of status for a particular animal. In other words, how is notice to the world obtained for the self-owned animal? How is any subsequent purchaser to know whether they are getting legal title or both legal and equitable title of the animal? A number of possibilities exist. One is to mark the animal with a tattoo of a universal symbol for that status. Then anyone seeking to purchase an animal would, by normal inspection of the animal, ascertain that the particular animal is equitably self-owned. Another possibility is to file the document in a specific depository where an inquiry can ascertain the status of an animal. This possibility still requires some method of identification of the animal so that the subject of the document can be clearly

75. Clealand v. Waters, 19 Ga. 35, 51 (1855).

76. A key requirement of the Roman law was that "the slave must have been the property of the testator, both at the death and at the date of the will." BUCKLAND, ROMAN LAW, supra note 68 , at 464 .

77. See id. at 449-59.

78. See CoBB, supra note 16 , at 296-305.

79. See id. at 288-95.

80. See Shaw v. Ward, 95 S.E. 164, 165 (N.C. 1918). Indeed, this case made reference to trusts for the benefit of animals to support its position.

81. Normally, for a private document of title to be effective, it must be delivered to the party receiving the interest or at least to a third party. This in itself becomes evidence of the intention of the transferor. See STOEBUCK \& WhITMAN, supra note 41, at 828-33. 
ascertained. While land deeds are recorded in the courthouse of the county in which the land is located, given the mobility of animals and their owners, an alternative to local recordings of documents is required. In the absence of a formal system, only a person who knew or should have known of the equitable self-ownership will be bound by the requirements of the new status.

The second method for creation of a new legal status for domestic animals is by operation of law, which can occur either by the actions of the judiciary or by adoption of new legislation. Change of status by operation of law might arise in a number of situations. As previously discussed, a wild animal under the personal ownership of a human will gain equitable (and legal) title if she is released back into her natural habitat. ${ }^{82}$ This is by operation of common law principles and does not require the actions or relate to the intentions of any human owner.

In the future, a legislature may find it appropriate to adopt legislation that would have the effect of causing the involuntary transfer of equitable ownership to a class or species of animals. For example, a legislature might decide that the scientific evidence of the nature of primates supports the proposition that every human owner of a primate should respect the nature of these primates and requires, as a matter of law, that equitable self-ownership be acknowledged for all primates held by humans. ${ }^{83}$

Once the separation of legal and equitable title occurs for any one animal, then the nature of having legal title will change, as the legal title holder must recognize and take into account the interests of the equitable title holder. Part of the nature of this obligation can be found in the area of trust law. Human animal owners are presently subject to the restrictions of anti-cruelty and licensing laws, but this is a duty owed to the states, not to the animals. ${ }^{84}$ If an animal had equitable title, then a legal title owner would have obligations both to the state and to the equitable title holder, the self-owned animal. By taking, assuming, or purchasing the separated legal title, a subsequent

82. See FAVRE \& BorCHELT, supra note 22, at 33-36; RAUSHENBUSH, supra note 12 , § 2.5 .

83. See generally Jane Goodall \& Steven Wise, Are Chimpanzees Entitled to Fundamental Legal Rights?, 3 ANIMAL L. 61 (1997) (suggesting that chimpanzees might be entitled to legal rights, although not using the property law approach suggested by this Article).

84. For an example of this, see the Michigan anti-cruelty law discussed supra note 38 . For an example of a licensing law, see MICH. COMP. L. § 287.262 (1996) (providing for extensive provisions for the licensing of dogs in the state of Michigan). 
human owner will also be subject to existing obligations toward both the state and the self-owned animal.

\section{Human Retention of Legal Title and Duty of Care}

While some authors have urged the elimination of the concept of title as it applies to animals, ${ }^{85}$ it is neither advisable nor feasible at this time. A key issue that the existing property law addresses is who is responsible for the care of this animal. Under our present system, full responsibility comes with ownership. ${ }^{86}$ Most animals within the domestic control of humans are not capable of self-care, regardless of their age, and if released or abandoned by their human owner would find themselves in an environment hostile to their existence. Therefore, at present, it is important that legal ownership continues to exist so that responsibility for the care of the self-owned animal can be squarely placed on a specific human.

Also for the foreseeable future, animals, even self-owned animals, could have economic value, and the only practical way to keep track of and transfer this value is through property ownership. Consider, for example, a racehorse. While the horse, Midnight, has her own intrinsic value as a living being, and this value is acknowledged by owner Jed who transfers her into an self-owned animal status, the horse will still have value in the external world of commerce. ${ }^{87}$ The new existence of equitable self-ownership does not preclude the realization of commercial value upon sale of an animal. However, the commercial value may well be negatively impacted, as the use of an animal must take into account the interests of the animal. $^{88}$

Another variation on the issue of value is what should happen at the death of the animal. If an animal dies, then self-ownership is

85. See Kelch, Non-Property Status, supra note 3, at 532.

86. Of course, this responsibility is broader than just a duty of care. Owners are also obligated for injuries caused by the animals they own. See FAVRE \& LORING, supra note 38, at 27.

87. A more radical view of the status of animals would urge the position that animals should not be bought or sold. In the author's judgment, society is not presently in a position to realistically consider such a concept.

88. An interesting focus point for future analysis is: should animals of the self-owned animal status be allowed to race or to participate in "athletic" events? The quick answer is a qualified "yes" as to horses, but "no" as to greyhound racing as presently configured. However, the rewards for the animal who wins might have to be more than a carrot and a few oats. Additionally, there is the issue as to whether the reward for the animal should arise for the effort or for the win. 
destroyed, and the owner of the legal title has full title in the physical body of the self-owned animal. In effect, there is a reversion of title back to the legal title holder. It is meaningless to talk of duty to the animal after it is dead; it is then no different than a rock.

Finally, the continued use of legal title will exist so long as different jurisdictions have different laws about the status of animals. If an owner takes an animal from a jurisdiction that does recognize equitable self-ownership into one that does not, then the laws of the jurisdiction where the animal is located will govern the relationship. Since legal title would always be present, there will continue to be certainty as to ownership and responsibility for an animal, regardless of where he or she travels.

\section{Some Attributes of Being A SElf-Owned Animal}

\section{A. Shift from Trustee to Guardian}

Having established the concept that an owner of an animal might have only the legal title, and thus be like a trustee, it is time for a modest word shift. While the term "trustee" was used in the prior analysis to build upon existing concepts in the law, it is not the best term to proceed with into the remainder of the Article. The trust concept was used as a bridge concept, because it supports the idea of dividing the title of property into its two parts, and because the owner of the legal title has a legal duty to the equitable owner of the property. Obviously, this new relationship is different in that the owner of the equitable title is also the subject matter of the legal title that is held by the human. Thus, there is a blending of corpus and selfownership in this new animal relationship that does not exist for a non-living asset trust. An additional distinction between a traditional trust and the one suggested for animals is that a trustee is an individual with legal title and a financial accountability to another, the equitable owner. When the subject matter of the trust is non-living property, this is fully appropriate. However, as this Article seeks to establish that living beings are different from non-living entities, the primary obligation of the legal title holder will not be financial accountability, but "being" accountability. The holder of legal title to a self-owned animal should be judged more in the context of a parent to a child than a bank to its customer. Such individuals may have some financial duties, like the parents of minor children, but the primary context for judgment of legal duties will be that of the quality 
of life of the animal. Thus, henceforth the holder of legal title will be referred to as the animal's guardian, while the holder of the equitable title will continue to be referred to as the self-owned animal.

\section{B. The Dimensions and Initial Contours of Equitable Self-ownership}

Having created a new legal status for animals, it is important to develop a context in which to describe the contours and consequences of this new legal status. This topic will require books to be written in the future, but for now, a brief view upon opening the door should be sufficient to understand the potential dimensions of the concept. After the creation of this new property status, nothing changes about the nature or interests of the self-owned animal, as they have no knowledge of what property status we might impose upon them. The changes will arise in how we humans consider and relate to the animals in question. The premier relationship being created is between the self-owned animal and the guardian. The nature of the duty toward the self-owned animal will arise out of two primary legal sources, anti-cruelty laws and the concepts developed for defining the parent-child relationship.

Upon opening the door into this new room of jurisprudence for self-owned animals, the viewer will immediately notice the decor of traditional equity along the walls and the ceiling. Standing in the door, the viewer can smell the mixture of fresh air blowing in through the window and the familiar odors of centuries of equity. It is a pleasing mixture, a mixture sure to draw the viewer into the room for a closer look. The source of the familiar odor is a certain mist in the room that does not allow crisp clarity of view but is comforting nevertheless. It is the broader concerns of equity, justice, fair dealing, and balancing of interests that have shaped the room. Equity, within the mist of the ages, has always sought to balance the conflicting interests of entities within its bounds when the law seemed inadequate to do so. Now that Zoe and the other self-owned animals have a room, there are new interests that existing concepts and legal principles must take into account. Zoe will provide flash and dashes of color as she tumbles across the floor and climbs this new furniture. For her it is just another room to explore, but for us there is much to contemplate as to what it might mean to have a cat sit upon the couch of "do not inflict harm or pain upon another." 
Closer in, the viewer will see several groupings of heavy furniture built upon the long-existing anti-cruelty laws. ${ }^{89}$ These laws provide a basic context for the specific obligations owed to all animals to assure freedom from "unnecessary pain and suffering," as well as the affirmative duty to provide for the physical well-being of animals (food, water, shelter, and veterinary care). ${ }^{90}$ But the colors and textures of this grouping are different than might be expected because while in other rooms the obligations upon which the furniture is built were owed to the state, in this room those duties of care are also owed to the self-owned animal.

What interests of the self-owned animal will the guardian need to take into account? The focus should be on life-supporting and species-defining activities. Consider the example of a human infant who has an interest in receiving food so he or she can live and grow. It is an interest recognized by adult humans and easily asserted, such that if it is shown that a human with responsibility is ignoring this fundamental interest of an infant for which they have responsibility, then the courts may intervene and do whatever is required to fulfill that interest. ${ }^{91}$ This can occur whether or not the infant has selfawareness of the interference with his or her self-interest. The human may or may not have breached the duty to the state as set out in criminal law, but the court will certainly have the authority to make sure that the needs of the child are met.

It is equally clear that a dog, a horse, or a snake has an interest in living, and that society presently expects those interests to be satisfied by the responsible human owner (keeper, trustee, or guardian). Thus, there have long existed the prohibitions or commands of criminal anti-cruelty law. ${ }^{92}$ The difficulty, until now, has been in allowing

89. The initial basis for laws protecting domestic animals was protection of economic value and seeking to limit morally unacceptable human behavior. After 1870, the law more and more justified its concerns on the pain and suffering of the animals themselves. See David Favre \& Vivien Tsang, The Development of Anti-Cruelty Laws During the 1800's, 1993 DET. C.L. REV. 1, 2 .

90. The first comprehensive anti-cruelty law was passed in New York in 1867. See id. at 18. Section 1 of that law prohibited unnecessary or cruel beatings or needless mutilation. Section 2 required for impounded animals "'a sufficient quantity of good and wholesome food and water." Id. at 33 (quoting N.Y. REV. STAT. § 375.2-.9 (1867)).

91. "The statutes authorizing the involuntary termination of parental rights .... enable the courts permanently to remove children from harmful parents or damaging environments ...." 2 Homer H. Clark, JR., The Law of Domestic Relations in the United States 631 (2d ed. 1987). The author details the considerable variability among the states as to circumstances justifying removal of children from their lawful parents. $I d$.

92. See Favre \& Tsang, supra note 89 , at 2. For a summary of existing anti-cruelty laws, see generally Pamela D. Frasch et al., State Animal Anti-Cruelty Statutes: An Overview, 5 ANIMAL 
anyone other than the state, through its prosecutors, to protect or assert the unfulfilled interests of nonhuman animals within either the civil or criminal side of the legal system. As it may now be asserted that the nonhuman animal has equitable self-interest within our new legal paradigm, civil equity courts should be available to hear claims of substantial interference with such fundamental interests. That a human recognizes the interference and asserts it on behalf of the selfowned animal does not diminish the legal vitality of the interest or the ability of a court to address this interference. ${ }^{93}$

For example, consider if Zoe was owned by someone who enjoyed the infliction of pain by extinguishing lit cigarettes against the cat. Today the state would have the right to bring a criminal action. But this would not help pay for the veterinary bills to help Zoe recover from the injuries. In our new room, Zoe could sue, certainly to obtain an injunction to stop the battery and additionally to recover at least actual damages in the form of veterinary care, if not also damages for intentional infliction of emotional distress, pain and suffering.

While the civil protection of interests could be done by government agencies, just as they do today for the protection of the interests of human children, in the world of limited resources it is more likely that private parties will be called upon to protect and assert the interests of the self-owned animal. Today the owners of equitable interests in a trust may bring an action to question the actions or inaction of the legal title holder of trust property, the trustee. While this will require the appointment of an equitable guardian ad litem, this is a natural process that courts can easily handle, with or without additional legislation. ${ }^{94}$

L. 69 (1999).

93. An animal can have rights without possessing the ability to claim them:

Capacity for rights (legal personality) must be distinguished from capacity for legal transactions, . . . capacity for wrongs, . . . and capacity for crimes .... A person may have legal rights and yet be incapable of legal transactions, or incapable of incurring legal liability, or incapable of incurring responsibility for what would otherwise be accounted crimes.

POUND, supra note 10, at 180-81.

94. During the period of slavery in Virginia, the courts on at least two occasions appointed counsel for actions brought by slaves. See Williams v. Manuel, 40 Va. (1 Rob.) 674, 678 (1843); Dempsey v. Lawrence, 21 Va. (Gilmer) 333, 335-36 (1821); see also Ross v. Duncan, Freem. Ch. (Miss.) 587, 642. 
If one has previously visited the room of jurisprudence concerned with the duty of the parent to the child, those shapes and colors will be strongly represented in our new room for the selfowned animal. The closest parallel to the nature of equitable selfownership and the relationship between legal and equitable ownership is that of minor children with their lawful guardians. It is the duty and right of the responsible adults to raise the children in a way they see fit, so long as certain critical interests of the child are met. Thus, the parent may discipline a child but may not abuse the child. $^{95}$ The parent must allow for the mental development of the child, ${ }^{96}$ as well as the appropriate level of food, water, and shelter for the child. ${ }^{97}$ The parent must also provide for medical assistance when the child has a need, even if it is against the religious beliefs of the parents. $^{98}$

Consider the present power of equity to deal with the relationship of human parent to human child. Every state has laws governing how a human can adopt a child ${ }^{99}$ and, thus, take on legal obligations toward the child. If the legal formalities are not met, then there is no adoption and no ability of the child to claim the status of heir to the adult. Thus, it is a "cut and dried" issue in the courts of law. But if the same court puts on its equity hat and believes a fundamental unfairness will result if a child is not found to have been adopted, the court could hold that an equitable adoption had occurred, with the result that the child can be considered the heir of the person who in all other respects acted as parent to the child in

95. "Child abuse, at least where it is likely to be repeated or where the parents have not responded to counseling and assistance, clearly is and should be a ground for termination of parental rights." 2 CLARK, supra note 91, at 633.

96. "It therefore is more realistic to say that the parent has an interest in and responsibility for the education of his child...."1 id. at 573.

97. "The most obvious forms of child neglect occur when the parent fails to provide for the child's elementary needs ... maintaining entirely inadequate or harmful living conditions." $2 \mathrm{id}$. at 639; State v. Bachelor (In re Interest of Bachelor), 508 P.2d 862, 866 (Kan. 1973) (citing a child's poor living conditions while in the custody of its parents as evidence of neglect).

98. See Jehovah's Witnesses v. King County Hosp. Unit No. 1, 278 F. Supp. 488, 504 (W.D. Wash. 1967) (upholding the declaration of Jehovah's Witnesses' children as wards of the court when their parents objected on religious grounds to proposed blood transfusions), aff'd, 390 U.S. 598 (1968); Sopar v. Storar (In re Matter of Storar), 420 N.E.2d 64, 73 (N.Y. 1981) (stating in dicta that a state's interest in protecting a child's welfare overrules a parent's refusal, based on religious belief, to provide necessary medical assistance); 2 CLARK, supra note 91, at 582 (noting an Illinois case ordering a blood transfusion for a child of a Jehovah's Witness).

99. For a general discussion of the issues surrounding adoption, see SCOTT FRIEDMAN, THE LAW OF PARENT CHILD RELATIONSHIPS 37-54 (1992). For more details, including citations to various state laws, see 1 CLARK, supra note 91, at 565-703. 
question. ${ }^{100}$ Thus, even in the absence of specific legislation, the courts can deal with balancing the interests of the parties before the court.

Likewise, there will have to be a balance between the desires and resources of the human legal title holder, the animal guardian, and the interests and needs of the self-owned animal. Just as the parents of the child must sort out what is in the best interests of their children, so the animal guardians must, in the first instance, decide what is in the best interests of the self-owned animal for whom they are responsible. If Mr. and Mrs. Neighbor have responsibility for Zoe, and they find themselves in the circumstances of separating and divorcing, then the issue of what to do with Zoe must be addressed. The issue will not be resolved by reference to who wrote the check for Zoe or which human wants Zoe the most, but rather what is in the best interests of Zoe. If Mr. and Mrs. Neighbor cannot reach that decision mutually, then the courts are empowered to step in and make that decision.

The second category of relationships is between the self-owned animal and others besides the guardian. As entities with legally recognized interests, self-owned animals have sufficient status as juristic persons so as to be able to hold equitable interests in other property. Thus, a chimpanzee with self-owned animal status could have an equitable interest in a building or a bank account. Property could come to him or her by gift, will, or perhaps through purchase by the guardian on the chimpanzee's behalf. The guardian of the selfowned chimpanzee will be a trustee for such assets with an obligation to use the assets for the interests of the equitable owner, the chimpanzee. The self-owned animal's interests will most likely be characterized as in the nature of a life estate or, perhaps, a fee tail. What if the self-owned animal should have assets at her death? As the possibility of an animal writing a will is not realistic, and some disposition of title is necessary, it will be presumed that the holder of the legal title of the property will obtain the equitable title, unless the prior owner of the asset has made other arrangements.

Besides these expanded property rights, a self-owned animal will have tort law available to protect his or her interests. For example, if a vengeful neighbor should shoot Zoe with a bow and arrow, two

100. See 1 CLARK, supra note 91, at 676 (stating that many courts honor claims of equitable adoption for inheritance purposes); George H. Locke, Annotation, Modern Statutes of Law as to Equitable Adoption or Adoption by Estoppel, 97 A.L.R.3d 347, 359-66 (1980) (identifying states in which the doctrine of equitable estoppel does and those in which it does not provide the child with inheritance rights). 
causes of action in tort will arise: the first by the guardian for losses to the guardian $^{101}$ and the second by Zoe for her losses and her pain and suffering. An interesting policy debate will be how to split punitive damages between the guardian and the self-owned animal. The flip side to this ability of the self-owned animal to sue will be the ability of others to sue a self-owned animal for injuries or damages caused by the self-owned animal. In other words, the law of torts, in a slightly modified form, will be within the room of jurisprudence set aside for the use of self-owned animals. Another area deserving of reflection and writing is the degree to which self-owned animals should partake in the contractual income or contest winnings that arise out of their efforts.

There are many possible topics of discussion once the issue of animals as juristic persons is taken under consideration. How can the legal system best accommodate, in an efficient manner, the protection of the interests of animals and the balancing of the interests of the self-owned nonhuman animal with the human animal? This author welcomes the thoughts and articles of others who are willing to enter into this new area of jurisprudence.

\section{CONCLUSION}

Animals are not humans and are not inanimate objects. Presently, the law has only two clearly separated categories: property or juristic persons. But, by using existing concepts of property law, it is possible to construct a new paradigm that gives animals the status of juristic persons without entirely severing the concept of property ownership. It is a blending of the two previously separated categories. The new status can initially be created by the actions of individual humans, but in time the legislature may want to speak on the topic and regularize some of the rules and relationships. Creating this new status will impose duties upon the guardians. The potential legal duties can be ascertained by reference to our long-existing anticruelty laws and the obligations existing within the parent-child relationship. When these sources do not provide a sufficient answer, the powers of the court of equity can be tapped to resolve disputes. With these steps, the issue of justice for nonhuman animals can begin to be addressed.

101. Multiple theories of damages are presently available to animal owners for injury to their animal: loss of fair market value, consequential damages, intrinsic value, mental suffering, and loss of companionship. See FAVRE \& BORCHELT, supra note 22, at 52-64. 